\title{
The Influence of School Culture Academic Supervision on Senior High School Teacher Performance in OKU Selatan
}

\author{
Ellen Oktarina $^{1 *}$, Yasir Arafat ${ }^{2}$, Achmad Wahidy $^{2}$ \\ ${ }^{I}$ SMAN 1 Buay Sandang Aji \\ ${ }^{2}$ Universitas PGRI Palembang \\ *Corresponding author.Email: ellen.azzam@gmail.com
}

\begin{abstract}
This study aims to determine the effect of principal academic supervision and school culture on the teaching performance of senior high school teachers in OKU Selatan. The study population was all state high school teachers in South OKU Regency with a total of 703 people. Sampling was done randomly and obtained 141 respondents. The research method uses descriptive quantitative methods. Data collection techniques through distributing questionnaires. The data processing of the research results was carried out using descriptive statistics with the method of partial correlation. The results of this study suggest 1) Principal academic supervision has a significant effect on teacher teaching performance. 2) School culture has a significant influence on teacher teaching performance. 3) Academic supervision and school culture together have an influence on teacher teaching performance; The magnitude of the influence of principal academic supervision and school culture on the performance of SMA Negeri OKU Selatan District teachers together is $23.5 \%$ and the remaining $76.5 \%$ is influenced by other factors not examined in this study.
\end{abstract}

Keywords: Academic Supervision, School Culture, Teacher Performance"

\section{INTRODUCTION}

Today's education is one of the determinants of a country's progress. Good and smart resources can be obtained through a good educational process as well. According to [1]. Currently, the government jointly and continuously aims to carry out the constitutional mandate in developing and advancing education, namely by increasing human resources (HR) which is believed to be an accelerator of the progress of a nation [1]. A quality teacher is a major milestone in the implementation of education at the level lowest which ultimately determines the improvement of human resources through the education sector. In (Happy: 104), [2] Anwar stated that according to students' perceptions a teacher has academic and academic authority non-, therefore students think that the teacher's influence on student learning is very large and decisive [3].

According to [4], one of the problems facing Indonesia is the low quality of teachers which results in questionable teacher and teacher professional performance [4]. Productivity / good performance can be achieved through improving the quality of work, resulting in an increase in quality and changes in better education, through regular and continuous supervision and guidance, the problem of teacher teaching quality can be resolved. Professional supervision of teachers can be carried out by the principal with the help of vice principals and senior teachers with the aim of developing the potential of students through quality learning activities served by the teacher [5][6]. In order to increase teacher professional accountability, the program that can be implemented is academic supervision. Academic supervision according to [4] can be interpreted as a process that can be useful in improving learning through assistance, guidance and / or coaching of supervisors to teachers. Thus, academic supervision is able to influence teacher professional abilities which can affect the quality of the teaching and learning process.

According to [5] [7] Supervision is considered to be the major planks of any strategy to improved the quality and standard of teaching learning process. From the above opinion it is known that supervision is a strategy to improve the quality of teacher performance and standards of the teaching and learning process [8]. Thus the quality of teacher performance can increase with the contribution of the principal in fostering teachers in schools through supervision and guidance activities. By always supervising and coaching, the success of the teacher's performance can be seen. In improving the performance and quality of teachers in schools, the principal has the authority to plan and carry out 
academic supervision of the principal which aims to improve teacher performance and ultimately improve the quality of learning.

Furthermore, it is said that performance is the result of organizational cultural values, which means that performance is a manifestation of existing cultural values. The work and work of superior quality can be realized if it is supported by human resources of superior quality. The strength of these human resources will mean a school culture. The core values of school culture are usually more philosophical and even somewhat similar to emphasizing the qualities that are the character of a school.

A good and conducive environment can be realized with the support of school members ranging from school principals, teachers, TU, students and other school members, good school habits, being nurtured and cultured can describe a good working climate that is related to work among peers. teachers, between teachers and school principals, between teachers and other education personnel and between agencies. This is clarified by the opinion of Hasanah [9] which states that school culture can be described through supportive attitudes, level of friendship, level of intimacy and cooperation. The conditions that occur in the four dimensions of school culture have the potential to improve teacher performance. An effective and productive school culture will have an impact on improving performance.

Based on observations, initial research information through informal interviews with the Principal and Deputy for Curriculum Affairs of SMAN 1 Muaradua and SMAN 1 Buay Sandang Aji on September 7, 2020, that supervision is carried out on average $2 \mathrm{x}$ a year, namely at the beginning of each semester of the school year. Supervision is carried out by supervisors consisting of the principal and assisted by the vice principal of curriculum affairs, the vice principal of student affairs, the deputy principal of the school for facilities and infrastructure as well as several senior teachers who are considered competent to supervise, this is because the principal's duties have resulted in many The principal rarely makes class visits during the teaching and learning process.

The supervision carried out is still not optimal, there are still obstacles so that it is not in accordance with the plan that has been prepared. There are still some teachers who propose changes to the supervision schedule because they still do not complete the learning administration, in this case there is no Learning Implementation Plan (RPP), this can be interpreted that some teachers still feel that the supervision program is something to be feared and feel "forced" to do the duty. There is also that the Learning Implementation Plan (RPP) made by subject teachers still does not meet good standards such as the discovery of learning plans using conventional methods, not involving technology. In addition, there is still the preparation of lesson plans that are very good, but when supervision is done, the implementation of learning is not in accordance with the lesson plans. In my opinion, this is due to the assumption that the lesson plans are made to fulfill administration only, teaching is not oriented to the lesson plans that are made. Then the problem that was also found was the follow-up action from the supervisor, sometimes it was only limited to assessing but not giving positive input and communicating the obstacles faced when teaching in class starting from the process of making lesson plans to evaluation.

\section{METHODS}

This research is a type of correlational research, namely a study to determine the relationship and the level of the relationship between two or more variables. The method used in this research is descriptive quantitative method. The study population was all state high school teachers in South OKU Regency with a total of 703 people. Sampling was done by random and obtained 141 teachers at SMAN 1 Muaradua, SMAN 1 Buay Sandang Aji, SMAN 1 Simpang and SMAN 1 Runjung Agung. The instrument to be used was tested first on 40 teachers outside the research sample, then tested the validity of the test results through validity and reliabilitytests. According to [13], it states that the validity of the instrument is shown through validity. [10] In analyzing the data the researcher used descriptive analysis, prerequisite analysis and hypothesis testing. The prerequisite test used in this study consisted of 1) Normality Test, 2) Linearity Test and 3) Multicollinearity Test. While the hypothesis testing was carried out by inferential test analysis consisting of simple regression test, multiple regression test, $\mathrm{T}$ test and $\mathrm{F}$ test.

\section{RESULTS AND DISCUSSION}

\section{Statistical Analysis Descriptive}

Based on data analysis, the data frequency distribution of the academic supervision variable obtained a minimum score of 59 and a maximum score. 100, median 85.00, mode 86 standard deviation 7.941 and the variance is 63.066. The data frequency distribution of school culture variables obtained a minimum score of 72 and a maximum score of 99, median 86.00 , mode 86 standard deviation of 4.986 and variance of 24.859. And the data frequency distribution of teacher teaching performance variables obtained a minimum score of 59 and a maximum score of 99 , a median of 87.00 , mode 91 standard deviation of 7.829 and a variance of 61.288 . The results of data processing can be seen in the attachment.

\section{Prerequisite}

\section{a) Testing Normality The normality}

Testtest is intended to determine endogenous variables in research that have a normal distribution or 
not. The normality test aims to study whether the distribution of the selected sample comes from a normal or abnormal population distribution [10] [11]. Testing Normality of data is done by Kolmogorov-Smirnov or test Liliefors and Normal PP Plot graph test using a significance level of 0.05. Data will be declared normally distributed if the significance is greater than $5 \%$ or 0.05 [12]. Normality testing through the PP Plot normal chart test is done by looking at the distribution of data (points) on the diagonal axis on the graph. In Figure 5 it can be seen that the points spread around the diagonal line and the distribution follows the direction of the line, so the decision making is based on the data obtained is normally distributed. While the results of the normality test through thetest Kolmogorov-Smirnov obtained asymp.sig (2-tailed) resultsfrom 0.112 academic supervision. School culture 0.280. and teacher performance of 0.117 . these values $>\alpha(\alpha=0.05)$, this proves that it is true that the data is normally distributed, so that the available data can be used for regression analysis.

\section{b) Linearity Test Linearity}

Test is used to determine whether the data obtained is linear or not. [10][13]. Linearity test aims to determine whether two variables have a linear or not significant relationship. This test is usually used as a prerequisite in correlation or linear regression analysis. Testing in this study using the SPSS 22.0 system using theTest for Linearityat a significance level of 0.05 .

Based on the results of the linearity analysis between the teacher performance variables and the principal's academic supervision, the value of Deviation from Linearity was 0.984 . This means that between the teacher performance variables and the principal's academic supervision have a linear relationship, because the value of deviations from linearity $>\alpha(\alpha=0.05)$, that is $0.984>0.05$. The results of linearity analysis between teacher performance variables and school culture, obtained a value of 0.233 . This also means that the variable teacher performance and school culture has a linear relationship, because the value of deviations from linearity $>\alpha(\alpha=0.05)$, which is $0.233>0.05$.

\section{c) Multicollinearity Test Multicollinearity}

Test is conducted to ascertain whether in a regression model there is intercorrelation or collinearity between independent variables [15] [14]. Multicollinearity test was used as a condition for multiple regression analysis. A good regression model should not find a correlation between these independent variables.

To see whether there is multicollinearity for each variable, the variable has a tolerance value $>0.10$ and a VIF value $\leq 10.00$. The results of the calculations obtained in table 26 show that the tolerance value for supervision is 0.895 and VIF 1.117 and the school culture variable has tolerance values at 0.895 and VIF at
1.117. This means that there is no multicollinearity between the independent variables in this regression model, which means that the resulting regression model is good.

\section{Results of Multiple Regression Analysis}

In this study, the hypothesis was tested using multiple linear regression models to obtain a comprehensive picture of the influence of academic supervision variables, school culture on teacher performance, which was carried out with the help of SPSS version 22.0. The results of multiple linear regression tests can be seen in the following:

\section{Table 1}

\section{Statistical Analysis of Multiple Correlation of Academic Supervision and School Culture Variables on Teacher Teaching Performance}

\section{Model Summary}

\begin{tabular}{crrcc}
\hline Model & $\mathrm{R}$ & $\begin{array}{c}\mathrm{R} \\
\text { Square }\end{array}$ & $\begin{array}{c}\text { Adjusted } \\
\text { R Square }\end{array}$ & $\begin{array}{c}\text { Std. Error of } \\
\text { the Estimate }\end{array}$ \\
\hline 1 & $.485^{\mathrm{a}}$ & .235 & .224 & 6,897 \\
\hline
\end{tabular}

a. Predictors: (Constant), School Culture (X2), Principal Academic Supervision (X1)

b. Dependent Variable: Teacher Performance (Y)

Source: SPSS Data Management 2020

a) Multiple Correlation

The results of multiple correlation analysis (R) based on the Model Summary output above obtained an $\mathrm{R}$ number of 0.485 between the supervision of the principal together with school culture on teacher performance.

\section{b) Determination Coefficient}

Based on the summary model table above, the coefficient of determination $\mathrm{R}^{2}$ ( $\mathrm{R}$ Square) is 0.235 , which means that the principal's academic supervision and school culture are able to influence teacher performance with a contribution of $23.5 \%$ while the remaining $76.5 \%$ is explained by factors that not included in this study.

c) Partial Hypothesis (T-)

TestThe $\mathrm{t}$ test aims to determine whether the principal's academic supervision variables (X1) and school culture (X2) partially (individually) affect the teacher teaching performance variable $(\mathrm{Y})$.

The magnitude of the regression coefficient (partial test) using multiple linear regression analysis can be seen in the following table. 
Table 2

\begin{abstract}
Multiple Linear Regression Coefficients Variable Principal Academic Supervision (X1) and School Culture (X2) Against Teacher Performance (Y)
\end{abstract}

\begin{tabular}{|c|c|c|c|c|c|}
\hline \multirow{2}{*}{ Model } & \multicolumn{2}{|c|}{$\begin{array}{l}\text { Unstandardized } \\
\text { Coefficients }\end{array}$} & \multirow{2}{*}{$\begin{array}{c}\text { Standardized } \\
\text { Coefficients } \\
\text { Beta }\end{array}$} & \multirow[b]{2}{*}{$\mathrm{T}$} & \multirow[b]{2}{*}{ Sig. } \\
\hline & B & $\begin{array}{l}\text { Std. } \\
\text { Error }\end{array}$ & & & \\
\hline (Constant) & 3,316 & 10,584 & & 2,825 & .000 \\
\hline $\begin{array}{l}\text { Supervision } \\
\text { of Academic } \\
\text { Head } .273 \\
.078 .277 .000\end{array}$ & & & & 3,523 & (X1) \\
\hline $\begin{array}{l}\text { School } \\
\text { Culture .499 } \\
.124 .318 .000\end{array}$ & & & & 4,035 & (X2) \\
\hline
\end{tabular}

a. Dependent Variable: Teacher Performance (Y)

Source: SPSS Data Processing in 2020

From the calculation results in the table above, the regression equation is obtained as follows: $\mathrm{Y}=$ $3,316+0.273+0.499+$ e. The value of 3,316 means that the value of the teacher's performance when the value of the principal's academic supervision and school culture is equal to zero or constant is 3,316 . This value indicates that teacher performance is influenced by the variables of the principal's academic supervision and school culture.

Based on the results of table 2, the partial regression results are obtained as follows.

According to the independent sample t-test test criteria, namely accept $\mathrm{Ha}$ if Significant Value (2tailed)> 0.025 and reject $\mathrm{Ha}$ if Significant (2-tailed) $\leq$ 0.025 (Basrowi, et al, 2007: 233) [12]. in Kesumawati, 2018: 107. This proves that thetest sample accepts Ha, which means that the academic supervision and teaching performance of SMA $\mathrm{N}$ teachers in OKU Selatan district is significant, this is evident from the (2-tailed) value of $3.523>0.025$.

The second criterion is based on the One Sample tTest which has the criteria of accepting $\mathrm{Ha}$ if the significant value $>a(a=5 \%)$. Sig value. $t$ of the principal's academic supervision (X1) in the table above is 0.000 whose value is less than $a=0.05$. This means that there is a significant relationship between the principal's academic supervision (X1) and teacher performance (Y) or it can be interpreted that Ho is rejected and $\mathrm{Ha}$ is accepted, so the hypothesis that "academic supervision of the principal is related to the performance of state high school teachers in South OKU Regency" is significant.
According to the independent sample t-test test criteria, namely accept $\mathrm{Ha}$ if Significant Value (2tailed)> 0.025 and reject $\mathrm{Ha}$ if Significant (2-tailed) $\leq$ 0.025 (Basrowi, et al, 2007: 233) in Kesumawati, 2018: 107. This proves that thetest sample received $\mathrm{Ha}$, which means that the school culture and teaching performance of SMA $\mathrm{N}$ teachers in OKU Selatan district is significant, this is evident from the (2-tailed) value of $4.035>0.025$.

The second criterion is based on the One Sample tTest which has the criteria of accepting $\mathrm{Ha}$ if the significant value is $<a(a=5 \%)$. Sig value. $t$ school culture variable (X2) in the table above is 0.000 which value is less than the value $a=0.05$. This means that there is a significant relationship between school culture (X2) and teacher performance (Y) or it can be interpreted that $\mathrm{Ha}$ is accepted so that the hypothesis that school culture and teacher performance at SMA OKU Selatan District is significant.

d) Simultaneous Hypothesis (TEST F) The

table below will display the ANOVA calculation results.

\section{Table 3}

Table of FTest Calculation

ANOVA $^{b}$

\begin{tabular}{llllll}
\hline Model & $\begin{array}{c}\text { Sum of } \\
\text { Squares }\end{array}$ & Df & $\begin{array}{c}\text { Mean } \\
\text { Square }\end{array}$ & F & Sig. \\
\hline Regression & 2015.151 & 2 & 1007,575 & 21,179 & $.000^{\mathrm{a}}$ \\
Residual & 6565,119 & 138 & 47,573 & & \\
Total & 8580,270 & 140 & & & \\
\hline
\end{tabular}

a. Predictors: (Constant), School Culture (X2), Principal Academic Supervision (X1)

b. Dependent Variable: Teacher Performance (Y)

Source: SPSS Data Processing 2020

From the table above shows that the calculated $\mathrm{F}$ value is 21.179. While the value of significant $F$ is 0,000 where the value is less than the stipulated value $a=0.1$ $(\mathrm{Pv}<\mathrm{a})$, this means that there is a significant influence on the principal's academic supervision (X1) and school culture (X2) together. on teacher performance (Y).

\section{DISCUSSION}

1. The Effect of Academic Supervision on Teacher Performance

The inferential analysis shows that partially the principal's academic supervision variable has a significant relationship with the performance of SMA Negeri OKU Selatan Regency teachers, where the partial test results (t test) of significance $t$ is 0.00 . And the descriptive analysis also shows that the academic supervision of the principal of SMA Negeri in OKU 
Selatan Regency is quite good. This means that the principal's academic supervision affects the teaching performance of teachers. The more often and the better the principal's academic supervision is carried out, the better the teaching performance of the teacher.

Based on the results of primary data processing from 141 respondents (teachers of SMA Negeri 1 Muaradua, SMA Negeri 1 Simpang, SMAN 1 Runjung Agung, and SMA Negeri 1 Buay Sandang Aji) that academic supervision has a strong enough effect on teacher teaching performance. This condition illustrates that the principal can foster academic supervision to influence teacher performance in carrying out duties and responsibilities, this can be seen from the answers to questionnaires from respondents who generally answer always (SL). This is also in line with the results of interviews conducted with school principals and representatives of curriculum affairs which stated that during the supervision activities there were no significant difficulties found, this was because it was supported by the existence of socialization from the principal or representative of curriculum affairs to all teachers. supervision, so that the teachers have prepared the necessary administration and prepared themselves for supervision. The preparations are made, namely preparing learning tools, learning media needed, and evaluation tools which are supporting documents for the smooth running of the school principal's academic supervision activities.

Based on the value of the recapitulation of the principal's academic supervision that has been produced which can be seen from the recapitulation document of the results of the supervision, it is found that the average teacher doing teaching performance gets a good score. Based on this document, the principal also carries out follow-up activities in the form of providing reinforcement to teachers who exceed standards by giving awards in the form of praise. In addition, the principal also provides the opportunity to take part in further training / upgrading.

Thus the better the academic supervision program carried out by the principal, the better it will improve and improve the teaching performance of teachers. The Principal's academic supervision program is based on the teacher coaching process that provides rich motivation for the growth of professional skills in teaching. He became an integral part of efforts to improve the quality of schools, received the support of all parties along with funds and facilities. Not a supplement or supplementary activity.

The academic supervision function of school principals according to [14] includes (1) planning, among others (a) identifying and determining academic problems, (b) developing supervision programs, (c) developing implementation mechanisms activities, reporting and follow-up, (d) preparing various instruments supervision needed, (2) implementation, among others : (a) implementation of supervision at the beginning and at the end of each quarter, (b) providing assessment and guidance, including educational and administrative techniques, (c) developing instruments educational supervision, (d) mastering the substance of the material to be supervised, in particular curriculum, teaching and learning activities and evaluation, (e) conducting continuous supervision, (f) involving educators in carrying out supervision, (3) reporting, among others : (a) legibility and implementation of the supervision program, (b) legibility and reliability of instruments, (c) problems in educational and administrative supervision, (e) results of supervision, (f) volume and frequency of supervision activities, (4) preparation of supervision plans and programs, (a) formulating guidance steps, (b) formulating policies, (c) containing data and information as official documents. (d) reinforcement and rewards are given to teachers who have met the standards, (e) warnings of an educational nature are given to teachers who have not met the standards; and (f) giving teachers the opportunity to take part in further training / upgrading. From the explanation above, it can be argued that the function of academic supervision is to make improvements to the learning process both at the preparation, implementation and evaluation stages of learning.

\section{The Influence of School Culture on Teacher Performance.}

Based on the inferential analysis conducted on the research respondents, the results show that partially the school culture variable has a significant relationship with the performance of state high school teachers in South OKU Regency, where the partial test results ( $t$ test) with significance $t$ is 0.00 . And in the descriptive analysis, the results also show that the culture of the SMA Negeri in OKU Selatan Regency is good, as seen from the answers of respondents who generally answered positively every statement in the questionnaire. This means that school culture has an effect on teacher teaching performance, which is a means of improving teacher performance.

Based on the results of an interview with one of the teachers at the State Senior High School in South OKU Regency, the culture developed in each school can be seen from the good cooperation of teachers, this can be seen at the flag ceremony in the presence of all teachers, collaborating to support programs programs carried out by schools, with high integrity and commitment. Besides that, a good culture can also be seen from high discipline through the routine habit of praying together, welcoming students at the school gate while shaking their hands. A good culture can also be seen through a program of discipline that is agreed upon and carried out jointly, so that the situation at school will run orderly for a long time because the program runs according to the rules of the game. The better the culture contained in SMAN in South OKU Regency and the more the culture is preserved, the better the teaching performance of the teacher. Increased teaching performance of teachers is the result of teacher internalization of the values of 
school culture so that it creates high loyalty and commitment to the school and instills a culture of intensive supervision of all school personnel from the principal which ultimately has an impact on improving teacher teaching performance.

The notion of culture is something that is abstract but still has a striking dimension, can be defined and can be measured based on general characteristics as stated by [14], namely as follows: individual initiative, to tolerate action at risk, the direction of integrity, support from management, control, identity, reward system, tolerance for conflict and communication patterns.

School culture is generally formed on the basis of one's vision and mission which is developed as an adaptation to environmental (community) demands, both internal and external. Each school must create its own school culture as a self-identity and also as a sense of pride in the school. School culture is a characteristic, character or character and image of the school in the wider community. The cooperation that exists between members has elements of a vision and mission, resources, a clear legal basis for structure and anatomy in order to achieve certain goals is a formal organization. The importance of building a school culture, especially with regard to efforts to achieve school education goals and improve school performance.

3. The Effect of Principal Academic Supervision and School Culture on Teacher Teaching Performance The

Results of the analysis show that the calculated $\mathrm{F}$ value is 21.179. While the value of significant $F$ is 0.000 where the value is less than the stipulated value $a=0.1$ ( $F$ count $<a$ ), this means that there is a significant relationship between the principal's academic supervision (X1) and school culture (X2) on performance. teacher (Y).

Many terms are almost the same as supervision, even in implementation, they are often used interchangeably, namely the terms supervision, inspection and inspection. Supervision means an activity to make observations so that work is carried out in accordance with the provisions. The examination aims to see how the activities carried out have achieved their goals. Inspection aims to find out deficiencies or mistakes that need to be corrected in a job.

Supervision is a process specifically designed to assist teachers and supervisors in learning daily tasks at school so that they can use their knowledge and abilities to provide better service to parents of students and schools, and strive to make schools a learning community. more effective. The point of supervision is to provide services and assistance. In line with the culture developed in schools in order to create a better nuance so that the two variables can increase the $\mathrm{Y}$ variable, namely the teaching performance of teachers in public high schools in OKU Selatan district.
The results of this study are also in line with the research that has been conductedby [15] the conclusion of this study is that the teacher teaching performance variable is influenced by the school culture variable and the school principal's academic supervision variable is accepted by $35.6 \%$. there is a value of $64.4 \%$ influenced by other variables that are not defined in this study. The standard error of the estimation value is 15.045 which is quite small which means that the data obtained from this study is quite fit for the resulting regression. The $\mathrm{F}$ test value of the regression is 8,148 with a Sig of $F$ change value of 0.001 indicating that together the principal's academic supervision variables and school culture are proven to affect the teacher's teaching performance variable [15].

Thus, through a well-functioning supervision program and a conducive school culture, good teaching performance will be created.

\section{CONCLUSION}

Based on the results of previous research and discussion, both through descriptive statistical analysis and inferential statistical analysis, as well as the findings in this study it can be concluded that the principal's academic supervision has a significant and positive effect on the teaching performance of state high school teachers in the district. South OKU. School culture has a significant and positive influence on the teaching performance of public high school teachers in South OKU Regency. And academic supervision and school culture together have a significant influence on the performance of public high school teachers in OKU Selatan district.

\section{REFERENCES}

[1] Mulyasa, E. (2013). Becoming a Professional Teacher Creating Creative and Fun Learning. Bandung: PT. Rosdakarya.

[2] Anwar, M. (2018). Becoming a Professional Teacher. Jakarta: Prenada Media Group.

[3] Fitria, H., Arafat, Y., \& Mardalena. (2020). The Effect of Academic Supervision and Teacher Professional Competence on Teacher Performance in Public Senior High Schools in Tanjung Raja District. Available on http://jurnal.radenfatah.ac.id/index.php/intelende kita ISSN 2303-2952, e-ISSN 2622-8491. Journal of Intellectuals: Islam, Social, and Science, Vol. 9, No. 1, June 2020.

[4] Priansa, D. J. (2018). Performance and Teacher Professionalism. Bandung: CV. Alfabeta.

[5] Regina, O. (2010). The relationship between principal supervisory strategies and teacher's instructional performance in Delta North Senatorial District Nigeria. Pakistan Journal of Social Science. 7, 437-440.

[6] Fuad, M., Subandi, S., \& Muslan, G. (2021). Teachers' Professionalism and Parents' Motivation in Learning Aswaja at Ma Tri Bhakti 
At-Taqwa Raman Utara. Bulletin of Pedagogical Research, 1(1), 1-15.

[7] Tampubolon, J. (2020). Supervisi Korektif untuk Menemukan Kekurangan-Kekurangan Guru Kelas dalam Malaksanakan Pembelajaran di SD Negeri 173105 Tarutung. Attractive: Innovative Education Journal, 2(2), 133-140.

[8] Pramesti, D., \& Muhyadi. (2018). Factors AffectingTeacher Performance High School. Yogyakarta: Universitas Negeri Yogyakarta. Terdapat Pada Harmoni Sosial: Jurnal Pendidikan IPS ISSN: 2356-1807 (print) ISSN: 2460-7916 (online) Volume 5, No 1, March 2018 (43-56) Online: http://journal.uny.ac.id/index.php/hsjpi.

[9] Hasanah, A. (2008). Produktivitas manajemen sekolah (studi kontribusi kepemimpinan kepala sekolah, budaya sekolah dan kinerja guru terhadap produktivitas sekolah menengah pertama di kota Bandung). Dissertation Universitas Pendidikan Indonesia Bandung.

[10] Kesumawati, N., \& Aridanu, I. (2018). Statistik Parametrik. Palembang: Noer Fikri Offset.

[11] Dwi, P. (2009). Mandiri Belajar SPSS. Jakarta: Bumi Kita.

[12] Basrowi., \& Soenyono. (2007). Metode Analisis Data Sosial. Kediri: Jenggala Pustaka Utama.

[13] Arikunto, S. (2006). Prosedur Penelitian Suatu Pendekatan Praktek. Jakarta: Bumi Aksara.

[14] Kadir. (2015). Statistika Terapan Konsep, Contoh, dan Analisis Data dengan Program SPSS/ Lisrel dalam Penelitian. Jakarta: Raja Grafindo Persada.

[15] Suhayati., \& Iis, Y. (2013). Supervisi Akademik, Budaya Sekolah dan Kinerja Mengajar. Jurnal Adminisistrasi Pendidikan Vol.XVII No.1. 